\title{
FILOSOFÍA Y POLÍTICA
}

\author{
Eduardo Carrasco \\ Universidad de Chile \\ educarr@manquehue.net
}

\begin{abstract}
Resumen
El artículo busca establecer las relaciones entre la política, entendida en su uso más común, y la filosofía. Para ello, se analizan e interpretan algunos fragmentos de Heráclito sobre "lo común" (Xunón) y las afirmaciones y experiencias de otros filósofos, como Nietzsche y Platón. En esta comparación se determinan rasgos esenciales tanto de la política como de la filosofía y se responde a lo que puede ser una relación no distorsionada entre ambas.
\end{abstract}

Palabras clave: filosofía, política, lo común, Nietzsche, Heráclito, Platón.

\section{Abstract}

We seek to ascertain the relations between politics, understood in the most ordinary sense of the word, and philosophy. To this end, we analyze and interpret some fragments of Heraclitus about "the common" (to xunon) and the assertions and experiences of other philosophers, such as Nietzsche and Plato. Through this comparison we fix some essential traits of both politics and philosophy and propose what could be a non-distorted relation between them.

Keywords: philosophy, politics, tòxunón, Nietzsche, Heraclitus, Plato.

$\overline{\mathrm{RA}}$ La frase de Nietzsche que leemos en "Schopenhauer como educador" (UB, p. 349), por la cual, según este pensador, la filosofía debería ser necesariamente indiferente a la política "...pues el que tiene el furor philosophicus en el cuerpo ya no tendrá de ningún modo tiempo para el furor politicus y se guardará sabiamente de leer los periódicos cada día y más todavía de servir a un partido", no parece haber sido escuchada por dos de los más grandes filósofos del siglo xx, Martin Heidegger y Jean Paul Sartre. Y debido a eso, una vez más se ha producido la catástrofe que desde los tiempos más remotos ha puesto a la filosofía en peligro, demostrando que cada vez que un filósofo ha dado pasos hacia las luchas de poder, sea por ingenuidad, sea por falta de tino, sea lisa y llanamente por equivocación, se cae en los mismos excesos y en los mismos desvaríos. Pareciera que Apolo se burlara de estos graves señores que con justificaciones filosóficas ambicionan entrar de algún modo en las luchas de poder, olvidando las ideas más básicas que la filosofía debe defender por su vocación libertaria. 
Pero esta Hybris, como todas las demás, los dioses mismos se encargan de que sea pagada, y al final es tanto el descrédito en el que la filosofía cae, que pareciera un trabajo titánico ponerla en pie de nuevo, aun en aquellos aspectos que menos incidencias podrían tener en los asuntos públicos.

El propio Nietzsche, desde sus primeros pasos en la filosofía, tuvo como ejemplo a Heráclito, quien despreció siempre todo compromiso con la política. De su actitud viene que el filósofo alemán haya puesto como una de las características esenciales de la filosofía el orgullo, esto es, la autarquía que hace que la mirada del filósofo se ubique por encima de todas las cosas mundanas. Los animales emblemáticos de Zaratustra son el águila, el animal más orgulloso bajo el sol, y la serpiente, el animal más prudente. Esta unidad de prudencia y orgullo es lo que desde esta perspectiva nietzscheana -que por su radicalidad filosófica nos interesa- se presenta como la esencia de la filosofía. Pero, ¿cuáles pueden ser entonces las razones que deberían obligar al filósofo a abstenerse de entrar en la política? Nuestro objetivo es, tomando como punto de partida estas afirmaciones, examinar las relaciones entre filosofía y política para determinar en esta contraposición cuáles pueden ser sus características esenciales y, si esto fuera lícito, cómo se pueden relacionar la una con la otra sin que se generen distorsiones como las citadas.

Tengamos en cuenta primero que el concepto de política ha incluido siempre una ambigüedad. Si observamos el uso común que se hace de él, vemos que en primer lugar él designa directamente la actividad de los políticos o de los ciudadanos que se involucran en ella, esto es, las diferentes acciones en vistas de adquirir el poder sobre los organismos públicos, por ejemplo, aquellas que brotan de la disposición a conformar agrupaciones o partidos con una determinada orientación ideológica, aquellas que surgen de la acción misma de estas agrupaciones con vistas a consolidarse y a influir en la sociedad (campañas, congresos, reuniones) y aquellas que constituyen pasos concretos hacia la toma o hacia la administración del poder (elecciones, acciones legislativas, gubernamentales, etc.).

Por otra parte, y en segundo lugar, la palabra "política" designa un aspecto de la existencia humana, el lazo que une a los hombres y que los mueve a vivir en sociedad, la condición de ser todos pertenecientes a una Polis y, en consecuencia, la particularidad de la propia existencia humana, que solo se hace digna de considerarse como tal cuando se abre hacia la realidad de otras vidas y cuando establece lazos por los cuales ella comparte el mundo con sus semejantes. En este caso, la política ya no es una acción o una actividad, sino un aspecto esencial de nuestra manera de ser. En este sentido, no está en las manos del hombre el hecho de ser o no ser político, hasta el punto de que la política ni siquiera es algo que se pueda elegir hacer o no hacer, pues derechamente no es algo que se "haga". Se es político, en cuanto el hombre, como decía Aristóteles, es un "animal político".

Y, finalmente, todavía hay una tercera significación de la palabra, que se refiere al pensamiento que busca dar una respuesta al problema de cómo debe ser este particular tipo de sociabilidad, incluyendo tanto la fenomenología de esta existencia con los otros, como la respuesta que podría darse al problema de cuál pudiera ser la 
mejor forma de organizarla y cuáles serían los fines y objetivos que ella tendría. En este último sentido -que indiscutiblemente también ha sido forjado por Aristóteles- la política se identifica con un cierto tipo de filosofía y no es otra cosa que la aplicación del pensamiento a los problemas de la organización y del funcionamiento de la Polis. Este tipo de pensamiento es lo que también se ha denominado "filosofía política", que no es una filosofía al servicio de un ideario político, cualquiera que este sea, sino un pensamiento vuelto hacia lo político, entendido en cualquiera de los dos sentidos anteriormente citados.

Notemos que cuando cuestionamos las relaciones entre filosofía y política, nuestras reflexiones no pueden tener que ver ni con la segunda, ni con la tercera de estas significaciones. Con la segunda no, porque nadie puede liberarse de esta condición, y tampoco el filósofo; y con la tercera tampoco, porque siendo la política misma una filosofía, no deberíamos encontrar ninguna contradicción entre ambas. La filosofía política se presenta como el ejercicio del pensamiento vuelto hacia esa temática, pero salvo en ocasiones en que el pensamiento se transforma en un medio de justificar determinadas posturas previas, este tipo de filosofía cumple con todas las exigencias que legitiman su cometido. El dirigir la mirada filosófica hacia las cuestiones políticas no debiera traducirse en una distorsión proveniente de prejuicios que opaquen su mirada. Esta debe mantener un distanciamiento frente a cualquier compromiso que le reste libertad, pues, como afirma el mismo Nietzsche, lo propio de la filosofía no es otra cosa que un intento de lograr la libertad de pensar sin trabas, ni prejuicios, ni parti pris.

Un concepto simple y pragmático de política en el primer sentido señalado podría ser el de una actividad realizada con vistas a ganar posiciones en la lucha por el poder sobre el Estado. Toda actividad política, cualquiera que sea su carácter, pacífica o violenta, tiene como objetivo la conquista de un poder sobre los órganos de las decisiones que conciernen a la Polis. Esta actividad recae en nuestra sociedad principalmente sobre los aparatos del Estado, pero también puede dirigirse a toda otra forma de agrupación social existente al interior de la sociedad que tenga que ver directa o indirectamente con éstos. La lucha es por obtener mayor influencia en las decisiones colectivas, por transformar las instituciones en instrumentos de la orientación que se le quiere dar a la sociedad en su conjunto. Por otra parte, y también en una primera aproximación, podríamos caracterizar a la filosofía como un intento de comprensión de los problemas que brotan de la particular situación humana, pero quedándose dentro de los límites que las propias facultades de comprensión del ser humano imponen. Intentar comprender qué somos, hacia dónde vamos -si es que vamos hacia alguna parte- qué es este mundo que nos rodea, o, derechamente, qué significa ser y qué relación puede haber entre el ser y el ente, pero todo esto sin echar mano a ningún factor exterior al ser humano -como podría ser, por ejemplo, la revelación de un Dios o las suposiciones que pudiesen surgir del libre juego de nuestra imaginación- es lo propio de la filosofía. Su carácter puramente descriptivo ha sido afirmado muchas veces, de la misma manera como su asiento en la libertad, entendiendo por libertad la no injerencia en sus modalidades de comprensión de tradiciones no sometidas a crítica o no asumidas por el propio pensamiento en el cumplimiento de sus propias exigencias. 
Así, la filosofía se presenta como el ejercicio del pensamiento sin ayuda, como la asunción en forma extrema y radical de la condición del ser humano, que busca darse una explicación coherente de sí mismo y de su mundo sin salir de sus propias limitaciones.

Nuestro propósito principal se dirige a determinar las relaciones entre esta forma de la política y esta comprensión de la filosofía. Por eso, algunas experiencias de filósofos pueden ayudarnos a llevar a cabo nuestro cometido.

Hemos afirmado que la política mediatiza otras luchas menores en vistas del fin general, hecho del que pueden surgir innumerables conflictos derivados. Esta mediatización puede llegar hasta causar la distorsión de otros objetivos, como, por ejemplo, los propios de las universidades o los de las municipalidades, que pueden ser menospreciados en vistas de la finalidad general política. Esta modalidad bastarda de la política, en la cual esta actividad se transforma en un fin en sí mismo, da lugar a lo que los franceses llaman la politique politicienne y es una de las causas por las cuales puede surgir un conflicto con otras instancias. Cuando esto ocurre, las instituciones pierden su finalidad específica, para comenzar a ser vistas únicamente como instrumentos de dominio. Pero esta misma tendencia a transformar la política en algo absoluto también subyace en casi todos los ámbitos en que esta se transforma en una actividad central, como, por ejemplo, en la acción de los propios políticos, quienes debido al carácter instrumental que pasa a tener para ellos casi toda acción social o cultural dentro de la sociedad, caen fácilmente en la ilusión de que su propia actividad es la más importante que pudiera imaginarse, y puestos frente a cualquier otra comienzan a hacer cálculos para determinar en qué medida ella favorece o dificulta sus propósitos. Esta forma distorsionada de la política, que también ha sido despectivamente denominada "politiquería" es, por cierto, un caso extremo, pero interesante de considerar, porque ella muestra este rasgo importante de aquella que es su peligrosa tendencia a la centralidad. Es precisamente esta tendencia la que genera los más fuertes conflictos con la filosofía, cuando esta última comienza a ser tomada como un mero medio de justificación o de fundamentación de determinados fines políticos.

La política aparece entonces como una actividad omniabarcadora y con una tendencia peligrosa. Todo se puede interpretar de acuerdo con la oposición de los intereses en lucha. Todo factor que intervenga en las relaciones de poder puede llegar a ser interpretado como favorable o desfavorable a dicha lucha, de donde surge el terreno fértil para la absolutización señalada, hecho que es característico de toda forma opresiva o dictatorial y totalitaria: todo es político, no hay nada que escape a las influencias de la política, no hay nada, ni nadie, que pueda pretender ubicarse en la neutralidad. Cualquier cosa que se diga o que se haga puede llegar a ser interpretada como un elemento que favorece o desfavorece las posiciones de poder que se trata de impugnar o mantener. La pesadilla en que se han transformado regímenes como el 
nazismo y el comunismo son una demostración de los estragos que puede causar esta situación. Pero la tendencia a la absolutización de la política no tiene solo estas manifestaciones caricaturales; también puede llegar a expresarse en formas aparentemente anodinas o democráticas. Estas pueden observarse fácilmente en el hecho de que la mayoría de los políticos se absorben de tal modo en su actividad, que no son capaces de hablar de otra cosa. El tema político los consume enteramente.

Puede afirmarse que la tendencia a la absolutización de la política está dada por el carácter absoluto del conflicto y por la compleja interrelación de los factores sociales. Es la razón por la cual para el político nada debiera dejarse de lado en sus análisis. Todo interviene en ellos: la economía, la información, la opinión pública, la investigación histórica, el derecho, la educación, la cultura, la ecología, el patrimonio, la religión, los valores, etc. La política, desde sí misma, no tiene por qué ponerse límites. Estos solo pueden provenir de otras actividades o intereses que se crucen en su camino, los cuales, por su propia dinámica interna de desarrollo, exijan una particular independencia. Ahora bien, si la filosofía, por su parte, exige para su constitución la libertad, es explicable que en lugares y momentos donde se ha producido una absolutización de la política se haya abierto también de inmediato una confrontación radical con la filosofía.

Recién recordábamos el modelo de Heráclito. Volvamos nuestra mirada hacia lo que, de acuerdo con los testimonios que tenemos de ello, fue su experiencia con la política. Según Diógenes, que recoge el testimonio de Antístenes, Heráclito era hijo del fundador de Éfeso, tenía derecho a los honores de rey y renunció a esta dignidad en favor de su hermano. Y no contento con esto, se automarginó de todo compromiso político: "Como se le pidió establecer leyes para ellos (los efesios), los despreció, porque, según él, la ciudad tenía desde hace largo tiempo ya demasiado malas costumbres políticas. Habiéndose retirado en las cercanías del templo de Artemis, jugaba a los "huesitos" con los niños. Los Efesios hacían círculo alrededor suyo y lo observaban jugar llenos de curiosidad. “De qué os extrañáis, vagos?” -les preguntaba - “No vale acaso esto más que administrar la república con vosotros?”. Finalmente, se fue a vivir de hierbas y de plantas a las montañas" (PP, p. 129).

Este distanciamiento es comprensible: la política se hunde en lo contingente, busca la acción directa, el resultado inmediato, y nace de una ilusión que el filósofo no puede compartir, la de que el hombre pueda modificar rápidamente algo que ya funciona de una cierta manera y que además está refrendado por usos y tradiciones. Las "malas costumbres políticas" a las que se refiere Diógenes no son mejorables en el corto plazo, y menos si el remedio que se busca reside en la palabra y el consejo de un filósofo. La filosofía no puede cambiar directamente el mundo; como Nietzsche lo dice poéticamente: "los pensamientos que mueven el mundo caminan con pies de paloma". La "acción" de la filosofía es subrepticia, va por rieles que no están a la vista de la mayoría de los hombres y se asienta en lo que tal vez sea el fenómeno más 
difícil de comprender: el modo cómo se abren paso a través de la vida de los hombres los verdaderos acontecimientos históricos, esos que a pesar de tenerlos en la punta de nuestra nariz, habitualmente se nos escapan completamente, esos que solo el tiempo muestra en toda su potencia, porque solamente a través del tiempo llega a delinearse su naturaleza.

Y es que los tiempos de la filosofía y los de la política son diferentes. La divertida observación de Nietzsche, que recomienda a los filósofos abstenerse de leer los periódicos, coincide con lo que vamos diciendo. Mientras la política tiene en vistas en forma predominante el presente, la filosofía, interesada siempre por la verdad en el sentido de lo que es o no es, busca un distanciamiento que la aleje de las ilusiones de la actualidad. Lo que se muestra de una cierta manera en el presente, con el tiempo resulta ser algo completamente diferente; lo cual exige tener en cuenta que el presente es el tiempo de la apariencia: en su ámbito se entrevera lo cierto con lo dudoso, lo permanente con lo pasajero, lo auténtico con lo falso. Es lo que ha dado lugar a que algunos historiadores hagan una diferencia entre los hechos y los acontecimientos. Los hechos son los sucesos del momento, que se van acumulando sin todavía poner al descubierto su sentido. Los hechos son lo que recoge el periodismo, lo que observamos en los informativos televisivos o lo que leemos diariamente en revistas y periódicos, sucesos en los que claramente se constata la necesidad de una interpretación para captar la dirección histórica hacia la que apuntan. Los hechos se acumulan unos tras otros y generalmente son recibidos por el lector sin ningún tipo de jerarquía o de ordenamiento profundo entre ellos. Las "secciones" de diarios y revistas se limitan a ubicarlos de acuerdo con criterios demasiado generales como para permitirnos desentrañar hacia dónde apuntan.

Los acontecimientos, en cambio, son las unidades más amplias en las que se inscriben los hechos y que permiten ordenarlos, dándoles a la vez un sentido. Estas grandes unidades históricas son las que en último término posibilitan hablar de "épocas" o de "períodos" y se presentan como espacios de tiempo en los cuales muchos hechos han tenido lugar, manteniendo una dirección determinada. Si nos acercamos a la determinación de los hechos, esto es, si los observamos desde cerca, solo se nos aparecen como realidades descritas y ordenadas por una sucesión temporal, en el sentido en que Heidegger habla de un "tiempo vulgar". Los hechos son ordenados según el tiempo aristotélico, según el número de lo anterior y lo posterior. Los acontecimientos, en cambio, exigen darle un contenido al tiempo, que ya no puede ser comprendido como un mero esquema formal de ordenación, pues todos los hechos que ocurren en su dominio apuntan hacia un mismo centro ordenador; de modo que lo que está ocurriendo en lo inmediato es el hecho, pero en forma mediata y a través suyo, el acontecimiento.

Los acontecimientos son unidades de muchos hechos en los cuales está ocurriendo algo que no se identifica con ellos, que los traspasa y los trasciende. Los hechos no pueden jerarquizarse si no se tiene en vista el acontecimiento al que pertenecen, de modo que considerados en sí mismos, todos ellos son equivalentes. Un hecho, por ejemplo, es la toma de la Bastilla el 14 de julio de 1789, el que, como tal, no posee ninguna significación más allá de él mismo, a menos que en su interpretación 
lo veamos como un significativo acto de subversión del orden existente en ese momento y un comienzo de lo que más adelante se llamará "Revolución Francesa". Pero sería un despropósito imaginarse que los participantes en ese hecho hubieran podido reconocerse como iniciadores de ese gran acontecimiento cuyas consecuencias siguen generando hechos hasta nuestros días, incluso hasta en nuestro propio y lejano país (Por ejemplo, la Ley de Cultos promulgada por el presidente Ricardo Lagos).

Stendhal, con su especial clarividencia, fue capaz de hacer esta diferencia entre hecho y acontecimiento y, además, de mostrar la distancia que hay entre ambos en la propia conciencia de los participantes de una historia. En La Cartuja de Parma, el joven protagonista, Fabricio del Dongo, resuelve ir a sumarse a las tropas napoleónicas reunidas en Bélgica para enfrentar a los ingleses. Allí vive una serie de peripecias bélicas y hasta resulta herido en una de ellas. Días mas tarde, ya lejos de los peligros que ha vivido, y leyendo las noticias que llegan desde el frente en las que se da cuenta de la derrota del ejército francés, el joven se pregunta: “¿Pero esto que he vivido era una batalla? ¿Y esta batalla era Waterloo?" A pesar de la corta distancia que lo separa de los hechos que ha vivido, ya comienza a aparecer el acontecimiento en el que ellos se inscriben (el final del Imperio napoleónico) y a Fabricio le resulta difícil hacer la relación y reconocer este último en los primeros. Y es que con los hechos nos ocurre lo mismo que pasa cuando en lugar de admirar el paisaje nos quedamos observando los cristales de nuestros anteojos. Nuestra mirada vuelta hacia lo inmediato se hace incapaz de ver lo más lejano. Así, la lectura de los periódicos infunde en nosotros la ilusión de que eso de lo que estos dan cuenta es lo que verdaderamente ocurre, cuando en verdad esto último solo aparecerá con el paso del tiempo y, entre otras cosas, su detección dependerá también de la penetración de pensamiento de la que seamos capaces para lograr trascender la observación de lo inmediato. De modo que la recomendación de Nietzsche a los filósofos, en el sentido de que se abstengan de leer los periódicos, tiene un atendible fundamento.

Por otro lado, la política implica siempre una toma de posición. Esto significa que ante la movilidad del proceso social-histórico, que se mueve siempre en un sentido difícil de desentrañar inmediatamente, la política se estabiliza en una perspectiva. La historia se mueve en una dirección que solo se revela cabalmente en el análisis del pasado, solo somos capaces de desentrañar la significación definitiva de los hechos pasados, y esto con gran dificultad. Pero la política contiene una cuota muy grande de voluntad y representa la expresión de un interés, de un deseo, de una fe, más que de un conocimiento. De ahí que con respecto a los hechos económicos o sociales, en nuestra modalidad actual de sociedad siempre hay por lo menos dos lecturas posibles, la de las dos tendencias que se enfrentan en la lucha por el poder. Que se hable de una "izquierda" y de una "derecha" en política significa que analizadas las cosas sin entrar en el detalle de las diferencias específicas de los partidos, siempre hay en grueso dos fuerzas que se oponen y dos perspectivas diferentes. La política, si bien siempre intenta apoyarse en conocimientos, estadísticas, informaciones de todo tipo, nunca se inclina verdaderamente ante el dictamen de estos datos. Lo que prevalecerá será siempre la voluntad de que las cosas vayan en el sentido de la posición que se ha tomado. De ahí que ningún análisis histórico sea más falso que aquél que se hace desde una 
determinada trinchera política. Los análisis son siempre necesariamente optimistas y esperanzadores, pues todos están reglados en sus resultados por la exigencia de favorecer las propias posiciones y perjudicar las del adversario.

Además, como decíamos, la política está necesariamente atada a lo contingente, los políticos generalmente están atentos a todos los indicadores de la situación inmediata, las noticias, las encuestas de opinión, los índices y las medidas económicas, etc., y eso le quita agudeza y penetración a sus miradas. No ven lo que el filósofo o el historiador son capaces de observar y que nace de un distanciamiento en relación con el presente, que les permite desentrañar en los hechos los signos del acontecimiento mayor en el que aquellos se inscriben. Las expresiones "nihilismo", "modernidad", "muerte de Dios", "Gestell", y otras como ellas, han surgido de esta observación distanciada y buscan dar cuenta de lo que las apariencias esconden y que sin embargo ocurre con mucha mayor fuerza y poder que cualquier hecho contingente. A los políticos estas afirmaciones les parecen un alejamiento de la realidad o una disquisición sin importancia, precisamente porque ellos están atentos a las relaciones causales inmediatas, a las consecuencias que tendrá en los electores tal o cual medida tomada, a los efectos de la subida del dólar o del precio del cobre, o a las consecuencias de las protestas o de los apoyos ciudadanos. En este sentido, puede afirmarse que la política y la filosofía no solamente viven en tiempos diferentes, sino, además, en cierto modo, contrapuestos, porque la atención a una modalidad del tiempo impide o dificulta la observación de la otra.

Por otra parte, la política es una apuesta hacia el porvenir. Hay política porque en lo inmediato no hay seguridad de que la historia vaya en una dirección determinada. Si esta certeza se tuviera, la política perdería su sentido. Ella es una afirmación de la acción humana en el conflicto de poderes y, por eso, en el sentido en que nosotros la conocemos, la política es moderna, pertenece al proceso general de autodeterminación de lo humano característico de la modernidad. Es un intento optimista de dominio de las condiciones sociales. Pero, como todo lo que es unilateralmente humano, la acción política está entregada a la determinación más radical de otros factores de la vida que ella misma no puede controlar: ella depende de esos factores que introducen una gran inseguridad en su cometido. De donde el interés de todo político en los signos indicadores de la dirección inmediata que parecen llevar los hechos, esto es, en lo que se llama "la opinión pública", y en toda investigación que pueda dar claves en la definición del acontecer contingente. Se comprende, entonces, que Heráclito, mucho más escéptico que el resto de sus conciudadanos no filósofos, haya visto con tanto desinterés su intromisión en la política.

La filosofía, por el contrario, tiene en vistas la verdad, lo que es, tal como es y lo que no es, tal como no es; esto quiere decir, sin ponerle a su visión condiciones que provengan de los intereses humanos. En este sentido, ella es la antiideología por excelencia. El filósofo tiene que pensar más allá del bien y del mal, es decir, más allá de lo que pueda considerarse bueno o malo para él o para los demás. Más aun, el filósofo está obligado a pensar realidades que pudieran volverse en su contra. Su inclinación hacia el ver no se mide por la conveniencia o inconveniencia humana de lo que descubre. El filósofo piensa lo "inhumano" o, si se quiere, lo que es destino, fatalidad. Por 
eso, en el filósofo toda demagogia está descartada. También todo lenguaje que no provenga de la directa relación con la cosa pensada.

Pero la sabiduría de Heráclito es todavía más fina y certera de lo que muestra esta primera anécdota citada. En lo que nos ha quedado de su escrito sobre la Physis, en los Fragmentos 1, 2 y 113, se habla de algo que no debiera ser jamás desconocido por los filósofos y que nos aclara qué asunto esencial han olvidado aquellos que han buscado entregar el pensamiento a los avatares de la historia y de la política. En efecto, al final del Fragmento 1 se dice lo siguiente: "En cuanto a los otros hombres (los que no son filósofos), lo que ellos hacen despiertos se les escapa, como se les escapa lo que ellos olvidan durmiendo" (HF, p. 29). Con esta frase se establece claramente un orden en el ocultamiento (olvido). Cuando estamos durmiendo, se nos escapa el mundo, nos adentramos en la región del completo ensimismamiento, en la que solo vemos lo que nosotros mismos somos capaces de crear, lo que sin mediación alguna somos capaces de ponernos delante. En ese estado, "fabricamos" un mundo, que en este sentido es completamente subjetivo, pues no se constituye a partir de ningún estímulo que provenga del exterior. El durmiente es un hombre recogido en sí mismo, que cuando despierta se abre a una "otredad" que ya no es su mundo interior. La sabiduría popular ha sintetizado este hecho en la expresión "mirar hacia adentro", con la cual se denomina el acto de dormir. Como lo afirma el fragmento 89, ese mundo del sueño no se comparte, no hay otro ser humano que en él participe, no hay otro que esté en lo mismo en que se encuentra el durmiente. "... hay para los despiertos un mundo único y común, pero cada uno de los durmientes se vuelve hacia un mundo particular" (HF, p. 63).

Muy diferente es el mundo de la vigilia, en el que estamos todos los que somos capaces de apartarnos de esa subjetividad hermética del sueño, para entrar en la realidad compartida. Ese es un mundo común, hasta donde sea posible eso común que es propio de este mundo. Porque la misma distancia que existe entre el ensimismamiento del sueño y el mundo compartido de la vigilia - u otra más radical todavía- es la que existe entre la superior visión del filósofo y la visión de esta realidad común cotidiana. Eso es lo que nos enseña la frase de Heráclito, lo que nos fuerza a hacer una distinción entre dos formas de lo común (Xunón): lo común de la vigilia cotidiana que se desmarca del ensimismamiento del sueño, y lo común superior a lo que accede el filósofo en su actividad pensante. Pues, también la vigilia en que vivimos cotidianamente es un grado de ensimismamiento con respecto a la supra conciencia del filósofo. El koinón kósmon, el "mundo común", es el mundo de los despiertos, pero así como hay un despertar del sueño, también hay un despertar de un grado mayor en la filosofía, que constituye su esencia misma y que le permite al filósofo acceder a un mundo común que no todos los demás hombres son capaces de ver. Así, el pensamiento aparece como una vigilia superior en la que accedemos a lo común superlativo, el Logos, aquello común que solo al filósofo, o al que piensa, le es dado ver. 
Pero, como en varios fragmentos lo expresa Heráclito, lo propio de esto común superlativo es que, si bien compromete a todos -en el sentido en que ello es lo propiamente común, eso en lo que todos estamos- no todos los hombres acceden a él o son capaces de observarlo. Lo cual quiere decir que lo verdaderamente común no se puede compartir en el ámbito de la vida corriente, en la vigilia del mundo y, por tanto, tampoco por todos los hombres, sino solo por los que piensan. Así, la filosofía aparece como una visión de lo común que paradójicamente es lo más alejada de lo común de la comunidad, pues esta última, por pertenecer a la realidad de la simple vigilia de primer grado, lleva implícita también su propia cuota de ensimismamiento. Esta vida común, en la que constantemente nos encontramos y que es el territorio de la política, lleva consigo el ensimismamiento que impide ver lo verdaderamente común, que es aquello que, competiendo a todos, no puede aparecer como tal en dicho ámbito. Así, tenemos: el ensimismamiento radical que corresponde al estado de sueño, el ensimismamiento relativo que corresponde al normal estado de vigilia, en el que se mueve la política, y el verdadero despertar, que corresponde a la filosofía, en el que todo ensimismamiento queda definitivamente abolido.

De la misma manera como el que sueña está enmarcado en los límites de su propia interioridad y vive así en la extrema subjetividad, el que vive en la vigilia del mundo llamado "real" también está alejado de lo verdaderamente común, pues está impulsado por intereses particulares, por visiones recibidas, por tradiciones y creencias que no son ni nunca podrían ser las de todos los hombres. Todo ser humano encara el mundo a partir de sus particulares intereses y por eso su mirada rara vez coincide con lo altamente común. Heráclito es el primero en definir el pensamiento como territorio de esto verdaderamente común: en el Fragmento 113 lo dice sin ambages: "Pensar es común a todos" (HF, p. 55). Esto no debe comprenderse en el sentido más trivial de ser el pensamiento algo que todos los hombres comparten por pertenecer a su esencia el pensar -cuestión que no requiere de ningún filósofo para ser afirmada, pero además, que se contradice con otras afirmaciones del mismo Heráclitosino en un sentido más decisivo y profundo, que Plotino comprendió acertadamente. En la Enéada VI (PE, 5, 10, 12) comenta precisamente esta afirmación de Heráclito y da como ejemplo ilustrativo de ella lo que ocurre en una reunión en la que los reunidos buscan el acuerdo: "...cada uno por separado es débil para llegar a un acuerdo, pero colaborando cada uno, en la reunión, a un solo plan y "concordando" realmente, alumbran y encuentran el acuerdo". El hallazgo del acuerdo que hace posible la concordancia es lo previo a ésta, de ahí que nos veamos obligados a afirmar que es esta última la que se constituye a partir de lo primero y no al revés como se entienden habitualmente estas relaciones. De este modo, el territorio del pensamiento es el dominio del acuerdo que hace posible la concordancia, que permite la unidad de los corazones que habitualmente están separados y que sorprendentemente ella vuelve a poner juntos. Así, el comprender filosófico lleva consigo la exigencia de salir del ensimismamiento para entrar en la concordancia a través de la escucha del acuerdo y, por eso, la suprema comprensión es la ascensión hacia lo extremadamente común, hacia aquello con lo que sería imposible disentir. A esto común se accede cuando logramos la suprema vigilia que consiste en la visión del Logos. 
Pero, obviamente, esta salida del disentimiento no tiene lugar, ni puede tenerlo, allí donde ocurre la vida cotidiana. Tampoco es una unidad de facto en la que todos los hombres se encuentren o puedan encontrarse a través del ponerse de acuerdo. Esto ocurre más bien al revés: es en la entrada en lo común donde puede llegar a tener lugar cualquier acuerdo. Concertar las opiniones solo es posible en la medida en que se haga presente lo común, pero esto último difícilmente podría surgir de una simple voluntad humana de acceder a lo que el otro afirma. Si tuviéramos que expresar esta situación, tendríamos que decir que las puertas de entrada en lo común solo están abiertas para el que piensa, quien, por su vocación, abandona el ensimismamiento de la vida cotidiana con todas sus tomas de posición particulares, con todos sus intereses individuales o egoístas, con todas sus perspectivas y puntos de vista limitados, para entrar en la zona libre del pensamiento sin trabas y observar desde allí lo que a los demás hombres les está prohibido. Pensar es despertar a esta supra vigilia a la que todos los hombres podrían acceder si se dieran el trabajo de llevar a cabo en sí mismos este proceso de liberación. Pero esto, indudablemente, no tiene por qué hacerlo cualquiera, y ni siquiera a cualquiera le está dada la posibilidad de hacerlo: se requiere de una vocación particular de abandono de la subjetividad y de un enorme esfuerzo por conquistar ese territorio. Se puede, sí, decir que lo común sería efectivamente compartido en el caso de que se dieran estas condiciones, pero como no se dan, la filosofía, a pesar de constituirse como palabra de lo común, está limitada al ejercicio de unos pocos, pero más todavía, también al acceso de unos pocos. No ha habido ni habrá jamás una filosofía de masas, como se pretendió en un momento de incontrolado optimismo público. Solo hay filosofía en individuos dispuestos a dar este paso de renunciar a lo propio para encontrar lo común. Las masas, por definición, viven en el ensimismamiento y son absolutamente incapaces de pensar. En todo movimiento de masas, el hombre se muestra sujeto a fuerzas que escapan completamente a su control y que tienen más que ver con los instintos y las emociones, con las ilusiones y las apariencias, que con el pensamiento.

Lo común no es lo que todos hacen suyo como común, lo que todos efectivamente comparten de manera consciente y voluntaria. No deben confundirse los consensos colectivos con esto común de que estamos hablando, pues los primeros pueden perfectamente consistir en una mera coincidencia de voluntades subjetivas: $1+1+1+1$ sigue siendo igual a $1+1+1+1$, su carácter de sumatoria no engendra la verdadera unidad en la que estas voluntades, independientemente de sus conscientes o inconscientes decisiones, están finalmente sujetas. En la realidad, la mayoría de los hombres más bien viven en la particularidad, la cual presenta dos modalidades: la particularidad del ego que se afirma a sí mismo, que lucha por sí y que pretende hacerse escuchar en la confusa batahola del mercado o en las oposiciones de la lucha por la vida, y la particularidad de los grupos que diferentes individuos forman, por medio de los cuales éstos buscan su propia autoafirmación a través de las múltiples asociaciones con otros, siendo lo que hemos llamado hasta hoy día "sociedad", la principal modalidad por la cual esto se lleva a cabo. Naturalmente, al interior de ella se entrecruzan, sin necesariamente oponerse, otras múltiples formas de asociación, cada una de las cuales le disputa a la otra la preponderancia. Así es como podemos ser 
latinoamericanos, chilenos, universitarios, hombres o mujeres, del campo o de la ciudad, trabajadores o estudiantes, artistas, empleados, católicos, protestantes, comunistas, liberales, negros, blancos o asiáticos, etc. Es decir, cada una de nuestras pertenencias es un modo de nuestra particularidad y cada una de ellas lleva consigo una perspectiva determinada desde la cual se observa al mundo o a los demás hombres. Esas pertenencias son precisamente la razón por la cual la vida cotidiana que llevamos nos aleja de lo común y nos obliga a vivir sumidos en la particularidad.

La política, en cuanto necesaria expresión de una parcialidad, es ciega a lo común y es necesariamente ideológica. Ella expresa siempre un deseo de que las cosas sean de una cierta manera. Se dirige principalmente hacia el porvenir y mira las cosas desde el punto de vista particular. Su lenguaje es el lenguaje de la tentación: se tienta al auditor con un discurso esperanzador. El "candidato" es precisamente la figura que expresa de mejor manera este rasgo de la política. Al "candidato" se lo peina, se lo viste, se lo arregla, se le indica lo que tiene que ocultar de su personalidad, se le sugiere que no haga demasiado ademanes o, al contrario, que debe hacerlos, se le entrega un punteo con los temas que el público querría ver tratados, se lo maquilla, etc. Es decir, en la política no interesa tanto lo que sean en verdad las cosas, como lo que aquellos que están defendiendo tal o cual punto de vista desearían que fueran. El lenguaje de la política se mide por lo que se desea representar. Esta representación tiene su expresión en la "propuesta". La "propuesta" es el factor desencadenante de todo el proceso político. Pero desde el momento en que hay "propuesta", hay la necesidad de que todo se mida desde ella. Yo propongo tal cosa y en función de mi propuesta, decido hacer tales y tales cosas. Lo que hago, deriva en primer lugar de lo que he propuesto. Pero, esto quiere decir que hay una precondición ideológica que tiene que cumplir la realidad. Esta precondición se puede ver claramente en el hecho recién citado de que después de las elecciones, todos los políticos ganan. Cada uno a su manera tiene que encontrar la forma de volver a darle solidez a sus posiciones: eso quiere decir que nadie reconocerá hidalgamente una derrota. Unos han dejado de ganar, que no es lo mismo que perder, otros han perdido en cierto sector de la población, pero han ganado en otro, otros han perdido, pero siguen avanzando porcentualmente con respecto a elecciones pasadas, en fin, todos se las arreglan para que sus cuentas salgan a su favor.

Sin embargo, desde un punto de vista formal, pero debidamente distanciado del acontecer inmediato, uno podría afirmar que el conflicto político es tal, únicamente porque es tensión de fuerzas que deberán resolverse en una síntesis. Esta síntesis, que difícilmente puede atisbarse en el momento mismo en que actúa la contradicción, se va mostrando a medida que nos alejamos de ella. Es porque existe esta síntesis que los pueblos tienen solo una historia y no todas las que relatan sus historiadores, aunque estas últimas siempre tengan como referente a la primera. Existe un referente común, aunque éste solo pueda observarse desde la distancia. Este es el que le interesa a la filosofía.

Pero, por otra parte, el político hablará siempre únicamente de lo que los hombres pueden hacer. Él esconderá el discurso sobre las determinaciones, sobre lo que no se puede controlar o calcular. No es político hablar de lo que impide la eficacia de la 
acción humana. Solo se debe hablar de lo positivo, de lo que somos capaces de hacer, e inclusive, si no lo fuéramos, de todos modos se tratará de mostrar lo imposible como un ámbito de acción posible. Tal vez en el largo plazo, pero posible. El esquema del pensamiento político es el del sujeto autónomo que opera sobre la realidad para modificarla en su favor, es decir, es afirmación del carácter absoluto del sujeto (cartesianismo) frente al objeto por modificar. La política pertenece al ámbito de influencia de la filosofía del sujeto, de la subjetividad o "subjetidad", como dice Heidegger. En este estricto sentido, podría afirmarse que no hay política antes de los acontecimientos que condujeron a la Revolución Francesa, o, más precisamente, antes de la afirmación de la autonomía del individuo (Declaración de los Derechos del Hombre y del Ciudadano).

Por tanto, mientras la filosofía se ubica en un terreno de lo común, tan extremo que hasta la perspectiva del hombre resulta un punto de vista cuya preeminencia no es siempre o necesariamente justificable, la política es siempre particular. En relación con la primera afirmación, basta recordar el espíritu de los diálogos filosóficos de Giordano Bruno, los sarcasmos de Voltaire frente a los particularismos o las afirmaciones de Nietzsche sobre la "objetividad" del filósofo. Giordano, por ejemplo, en el Cuarto Diálogo de Causa Principio y Unidad afirma que "a pesar de los innumerables individuos, cada cosa se remite a la unidad, y el conocimiento de esta unidad es el fin y el término de todas las filosofías y de todas las contemplaciones naturales" (CPU, p. 179).

Ahora bien, en la sociedad hay formas regulares de lo común, que en cierto modo se presentan como suplantadoras de la verdadera comunidad. Por ejemplo, aquellas que brotan de las formas de asociatividad directa, esto es, aquellas que tienen lugar a través de los lazos dados por valoraciones dominantes o por circunstancias ideológicas o religiosas que son transmitidas por tradiciones familiares o de grupos. En estos casos, podríamos afirmar que se trata de ciertos factores que aparecen ilusoriamente como permanentes, como si fueran el sustrato mismo de la sociabilidad, cuando en realidad son simplemente mayoritarios o compartidos por sectores influyentes, pero que no comprometen a la totalidad de los ciudadanos. Así, por ejemplo, se puede llegar a considerar que un país es predominantemente "católico" o "protestante", aunque en la misma sociedad donde estas formas de religiosidad existen, coexistan con ellas otras formas de religiosidad $u$ otras maneras de pertenencia que no sean religiosas. Cualquiera de estas formas de asociatividad, incluso si ellas son efectivamente mayoritarias, no podría ser considerada como equivalente a lo verdaderamente común, pues ello debería incluir también las realidades de las minorías. Así, todo grupo dentro de la sociedad, por más numeroso que sea, no puede identificarse con el factor de íntima cohesión en el que la propia sociedad se constituye como tal. Esto es lo que ha llevado a distinguir y separar aquellos aspectos que verdaderamente unen a todos los ciudadanos y aquellos que los dividen, y esta situación ha sido la base de la 
histórica separación de la religión y el Estado en las sociedades democráticas y el fundamento de la laicidad.

La República es, como lo dice su nombre, la res publica, es decir, el ámbito en el que tienen lugar y se deciden los asuntos que nos competen a todos en cuanto ciudadanos, por encima y más allá de cualquier posicionamiento privado. La res publi$c a$ es un territorio diferente al de lo privado, que es lo que nos compete en cuanto individuos que hacemos elecciones de vida que no tienen por qué compartir todos los que conviven con nosotros y que forman también parte de la nación. En una nación democrática, lo privado y lo público están obligados a convivir en armonía, pero para que ello sea posible, lo privado debe asumirse como privado y no pretender entrar a suplantar lo público y, por su parte, lo público debe remitirse a actuar en su territorio sin pretender reglar lo que pertenece a nuestra privacidad. Cuando se confunden estos planos, rápidamente se comienza a rodar por el despeñadero del autoritarismo o del sectarismo. Pretender legitimar en el ámbito público lo que solo puede tener validez en el privado, significa en los hechos negar lo primero, pues ello solo puede tener existencia en la medida en que opere en él la neutralidad necesaria para que queden representados en su ámbito todos los ciudadanos.

Por ejemplo, por más numerosa que fuese una religión, ella no representaría más que a un grupo dentro del conjunto de la sociedad, quedando fuera de ella todos los que de un modo u otro no la comparten. Esto significa que toda religión o grupo religioso pertenece al ámbito privado y que sus autoridades debieran abstenerse de pretender hacer prevalecer dentro del ámbito público las ideas que corresponden a su fe. Todo ciudadano, ante la República, tiene el deber de pensar aquellos aspectos de su vida que nos conciernen a todos, desde el respeto que merece nuestra diversidad. Pretender hacer prevalecer como legítimo para todos lo que solo es válido para algunos, es avivar contradicciones insolubles y actuar de modo sectario y autoritario. Y toda religión debiera aprender a no salir del ámbito privado. Cuando esto ocurre, se confunden inmediatamente los planos y algo que tiene más que ver con valores que se presumen eternos y propios de una vida que no es la que regulan nuestra leyes y administran nuestras instituciones, se ubica en el plano del "más acá", apareciendo más como una ideología política o una posición contingente, que como una verdadera opción espiritual.

Es importante considerar que los particularismos políticos, los partidos o movimientos que encauzan su acción por las vías democráticas, se diferencian de estas posturas religiosas en cuanto encuentran en el propio ámbito político una manera de legitimar sus disensiones. Las creencias religiosas se disputan a los fieles sin poseer ningún terreno común en el cual puedan enfrentarse. Históricamente, cuando estos enfrentamientos han tenido lugar, ellos siempre han tomado inmediatamente formas violentas. Y es que las religiones, en cierto modo se recluyen dentro de sí, excluyendo a las demás, a diferencia de los partidos, que logran aceptar mutuamente sus diferencias y combatir en escenarios comunes donde expone cada cual sus ideas, en la aceptación del derecho a la libre adscripción de los ciudadanos a ellas o a otras. La política misma puede concebirse precisamente como este terreno común, hasta el punto que para algunos pensadores la desaparición de él en las dictaduras significa no solo el 
término de los debates o de las posibilidades de elección, sino lisa y llanamente el fin de la política. Así, podría identificarse la condición de posibilidad de la política en la democracia, sin la cual este terreno de confrontación pacífica y regulada por leyes, desaparece. El ámbito en el que se constituye esta posibilidad es lo que se denomina habitualmente "laicidad".

El término "laicidad" remite a la palabra griega "laos", que significa la unidad de una población, aquello que es común en ella. Laicidad significa que ninguna creencia o ideología debe identificarse con el Estado o gozar de ventajas que puedan conducir a una discriminación. Sin embargo, la laicidad no es un pensamiento contrario a la religión. Los defensores de este pensamiento en Chile en su mayoría fueron creyentes. Se puede ser laico sin renunciar a ser católico, protestante o agnóstico. La laicidad es la afirmación positiva de que aspectos fundamentales de nuestra vida pueden ser abordados más allá de nuestras divisiones o separaciones políticas, ideológicas o religiosas. En definitiva, ser laico significa afirmar que lo que compete a nuestra vida en común debe ser abordado desde principios que nos unen a todos, poniendo entre paréntesis aquellos que nos separan, es afirmar que el espacio público es un terreno de neutralidad que debe representar legítimamente a todos los ciudadanos y asegurar de este modo la confrontación pacífica de los diferendos, es el pensamiento republicano, que busca legislar y tomar decisiones de Estado desde lo que nos es común, sin pretender obligar a otros a someterse al dictado de nuestras propias preferencias. Ser laico es respetar el derecho de ser minoría y aprender a ubicarse en un terreno donde todos podemos estar de acuerdo. Este terreno, ubicado más allá de las confrontaciones de intereses particulares ha sido precisamente abierto por la filosofía desde el origen de la modernidad, aunque sus bases, como se ve, echan raíces en el origen mismo de la civilización occidental.

Por tanto, toda particularidad es un obstáculo para el pensamiento, en la medida en que este está obligado siempre a buscar la unidad, la que finalmente en su modalidad más exigente se encuentra en la idea de la unidad de todo, en el "Todo Uno" de Heráclito, que, según él mismo lo dice en el fragmento 50, es la marca de la suprema sabiduría. "Es sabio que aquellos que han escuchado, no a mí, sino al Logos, convengan en que todo es uno" (HF, p. 23). Elevarse por encima de las particularidades, incluso de aquellas que parecieran más imposibles de superar, como, por ejemplo, la pertenencia a un pueblo o a una nación, pareciera ser la condición que debe cumplir todo filósofo. En Schopenhauer como educador, en el número 7, donde Nietzsche resume las condiciones de vida que favorecieron la transformación de Schopenhauer en un filósofo, la segunda anotada es este necesario distanciamiento frente a las limitaciones nacionales: "Muy temprano, él se armó de indiferencia con respecto a las limitaciones nacionales, hasta llegar a mostrarse incluso demasiado riguroso hacia ellas; él vivía en Inglaterra, en Francia, en Italia, igual que en su propio país y no simpatizaba poco con el espíritu español" (UB, p. 349). El filósofo, por lo tanto, no puede ser nacionalista. El hecho de que una filosofía, desde un punto de vista historiográfico, es decir, desde una perspectiva puramente descriptiva, pueda ser relacionada con un país, con un paisaje, con un grupo humano, con un Estado, no debe hacernos pensar que estas condicionantes de su aparición revelen lo esencial. Es la 
filosofía misma la que a partir de su propio poder configurador de historia genera sus propias particularidades, definiéndose como "europea" y, en la medida en que es lo europeo lo que se globaliza, también planetaria. Pero la vocación de universalidad y de tolerancia es quizás uno de los mayores aportes que la filosofía ha hecho a la humanidad.

Al revés, como decíamos, la política es necesariamente unilateral. La desesperación del político es que frente a cada posición esgrimida o avanzada surge una posición diferente y, en muchos casos, contraria. Esta unilateralidad no hay que entenderla en el sentido de un necesario relativismo. Se trata de una unilateralidad proveniente de la lucha de intereses imperante en la sociedad. Pero, desde una perspectiva exterior a la política no habría por qué privilegiar uno de los lados frente al otro. (Como afirma Nicanor Parra: "La izquierda y la derecha unidas, jamás serán vencidas"). Cada cual tiene sus propias razones, sus propias justicias, sus propios sueños y sus propias apuestas sobre lo que es mejor para todos. La mayoría actúa de buena fe, aunque algunos, como el tiempo va demostrando indefectiblemente, cometan equivocaciones que pueden llegar a tener terribles consecuencias. Pero, debido al carácter conflictual de la política, la equivocación en ella no puede ser dirimida en su propio terreno. Por eso, en este sentido, los políticos siempre tienen la razón, su razón, y rara vez se equivocan. Un buen ejemplo de esto es la valoración que hacen los distintos sectores políticos chilenos de la reciente historia: frente a las atrocidades cometidas por el régimen militar, denunciadas en informes de organismos de cuya neutralidad no es posible dudar, ninguno de los personajes señalados como responsables asume esto como equivocación. Son excesos comprensibles y exigidos por la situación de guerra que se vivía. Se trata de acciones enteramente justificables desde la valoración que surge desde los principios de su política. Como el adversario se preparaba para cometer los peores crímenes, los peores crímenes en su contra quedan justificados. El fin justifica los medios. Por su parte, tampoco los responsables políticos de izquierda asumen derechamente sus errores: fueron víctimas de la crueldad del contrincante, de las manipulaciones de la CIA, de las acciones sediciosas que boicoteaban las medidas positivas del gobierno, etc. No es nuestro propósito desconocer las diferencias entre las razones de las víctimas y las de sus victimarios, pero es la historia misma la que se encarga de ir abriéndole paso a una razón que es cada vez más cercana a lo común y en la que las diferencias que hubo en el pasado se atenúan.

Frente a las interpretaciones partidistas, el tiempo va abriéndole paso a visiones más objetivas, lo cual señala que frente a todo acontecimiento existe una posible mirada, diferente a la que los políticos son capaces de tener en el momento en que los hechos conflictuales se producen y que finalmente acierta a poner las cosas en su lugar. Desde Heródoto y Tucídides, la historia, es decir, la investigación sin prejuicios sobre los hechos políticos, puede finalmente dirimir responsabilidades y explicar las cosas de un modo mucho más sereno, acertado y objetivo. Recién hoy día podríamos, por ejemplo, dirimir responsabilidades ante los sucesos que condujeron a la revolución de 1891, o a las confrontaciones entre O'Higgins y Carrera, o a las causas y consecuencias de la Independencia. Pero, en general, frente a los sucesos históricos, las razones de uno se contrapesan con las razones del otro, abriéndose con ello un 
extraño espacio de neutralidad, que es lo que al filósofo le interesa. Es este espacio de neutralidad lo que define un límite que la propia política no puede darse, y que establece una exterioridad con respecto a ella, que hace posible una investigación o un saber no partidista.

¿Pero de qué manera es posible ubicarse más allá de estas instancias? ¿No es acaso la filosofía una de las tantas ocupaciones humanas, la cual necesariamente deberá afincarnos en intereses y miradas específicas? ¿Cómo le será posible al filósofo atravesar estas pertenencias y conducir su vida hacia las alturas de lo común? La respuesta a esto es justamente el pensamiento. Tal como lo ha expresado genialmente Heráclito, no es que el pensamiento sea de lo común porque tenga a esto común como objeto, no es que busque lo común como un terreno donde él se ejerza. Lo común, en realidad, es la esencia del pensamiento, pensar es pensar lo común. El fragmento 2 lo dice claramente: "mientras el Logos verdadero es lo común, la mayoría vive teniendo al pensamiento como algo particular" (HF, p. 57). El Logos verdadero no se confunde con lo que cada cual pueda imaginarse, teorizar, creer u opinar por sí mismo. La mayoría piensa que por ser capaz de emitir opiniones, expresar su punto de vista, mostrar con palabras lo que se le ocurra, está ya pensando, pero la verdad es que solamente cuando somos capaces de elevarnos desde estas perspectivas particulares hacia lo común, estamos de verdad ejerciendo el pensamiento. Lo común, insistimos en ello, no aquello en lo que todos desde nuestros puntos de vista particulares concordamos, sino ese espacio que abordamos cuando emerge ante nuestra mirada lo común mismo, eso que independientemente de las desaveniencias debiera ser afirmado por todos, si todos fuéramos capaces de acceder a él. Plutarco en De la superstición, 3,166c, afirma que "Heráclito dice que para los despiertos (los que ven el Logos) hay un mundo único y común, pero que cada uno de los dormidos (los que no tienen acceso al pensamiento) se vuelve hacia un mundo particular" (HF, p. 63). Así, los hombres despiertos y dormidos están separados por un abismo imposible de franquear, a menos que se lograra que todos fueran capaces de pensar, lo que está excluido por el propio carácter de la naturaleza humana. Lo hombres se dividen entre los despiertos y los dormidos, constituyendo estos últimos la mayoría.

Una mayor aproximación a la naturaleza de esto común nos la entrega el Fragmento 114: "Los que hablan con inteligencia (porque piensan) extraen su fuerza necesariamente de lo que es común a todo, como la ciudad extrae su fuerza de la ley, y mucho más fuertemente. Pues ellas, las leyes humanas, se alimentan todas de una sola ley, la divina: porque ella domina a todo lo que ella quiere, ella basta para todas las leyes, y a todas ellas, ella sobrevive" (HF, p. 217). La ley divina rige sobre todo, y el que la tiene bajo su mirada es capaz además de dar testimonio de su particular poder, que es más fuerte que el poder que tiene la ley sobre la ciudad. ¿Cuál es este último? ¿Cómo debemos comprenderlo? 
En Grecia ha surgido esta especial forma de legislación que los ciudadanos se dan antes de constituirse como Polis. Esto, probablemente haya sido así debido al hecho de la fundación de las ciudades como colonias. Por causa de la particular configuración predominantemente montañosa de la península de los Balcanes, en la que los valles cultivables son relativamente pequeños y no permiten grandes concentraciones de habitantes - pues la hambruna invernal diezmaría las poblaciones-a partir de un cierto grado de crecimiento, las ciudades originales comenzaron a enviar a parte de sus habitantes al exilio. La mayoría de estos emigrantes eran jóvenes y salían en busca de un territorio nuevo donde pudieran fundar la nueva colonia. Ésta tenía que construirse sobre bases nuevas, lo que hacía necesario darse una constitución y leyes que generalmente les eran encargadas a los más sabios y, en algunos casos, a personalidades que no necesariamente pertenecían de la comunidad. Así, las legislaciones no eran únicamente el fruto de viejas tradiciones que perduraran a través del tiempo y que se hubiesen trasmitido de generación en generación -como ocurre efectivamente en otros pueblos antiguos- sino que se discutían y se asumían por el conjunto de la comunidad a propuesta de los legisladores. Este hecho ha sido puesto en relieve por algunos tratadistas (por ejemplo, por Cornelius Castoriadis ${ }^{1}$ ) como el verdadero origen de la democracia griega y, consecuentemente, de la propia filosofía. Filosofía y democracia nacen al mismo tiempo (siglo vi a. C.), pero se requieren una a otra en una relación en que cada una de ellas aparece como condición de posibilidad de la otra: sin el espacio de apertura y de liberación de los factores consuetudinarios que caracterizan a la democracia no es posible la filosofía, y, a la vez, sin la discusión sobre cómo ha de organizarse la ciudad y de acuerdo a qué valores que viene con la filosofía, no es posible la democracia.

La ley griega toma su fuerza de la aceptación común por parte de los ciudadanos. Estos se atienen a la ley, porque ellos mismos se la han impuesto. La fuerza viene de lo que se ha establecido como común. La ley misma se ha establecido como lo común, como la obligación que todos y cada uno de los ciudadanos ha aceptado y ha asumido. Por eso, el que habla en nombre de la ley extrae la fuerza de esto común y todos debieran consiguientemente someterse a su dictamen. Eso explica el fragmento que comentamos, pero también la anécdota que recuerda Diógenes sobre la petición de leyes que le hacen a Heráclito los ciudadanos de Éfeso. Como, además, este último era descendiente de los fundadores de la ciudad, es natural que hayan podido pensar en él para llevar a cabo esta tarea.

En el caso del sabio, que habla con inteligencia, la fuerza de su discurso proviene de lo que es común a todo lo existente, eso que opera como una especie de ley, pero que no solo rige los asuntos humanos, sino además lo que compete a todo ente, por el hecho de ser un ente. Ahora bien, este hablar de los despiertos pone de manifiesto lo común, porque habla desde lo común, no emite una opinión personal o un punto de

1 Cornelius Castoriadis, (2004), Ce qui fait la Grèce. D’Homère à Héraclite, Séminaires 19821983. La Création Humaine II. Paris: Éditions du Seuil. 
vista particular, que es el suyo, sino que es capaz de ubicarse en la visión de esa suprema vigilia que hemos mencionado antes, donde lo común se manifiesta. Así, la fuerza de este discurso no extrae su poder de una aceptación general, como es el caso de la ley de la ciudad, sino de la potencia divina que lo rige todo. Eso explica que el discurso filosófico no dependa de que otros lo compartan, sino que es autárquico, autosuficiente, en cuanto se cumple simplemente por el propio decir de la unidad. Este decir es el decir del filósofo, pero, por ello mismo, es el decir del Logos. El que lo escucha debe aprender a escuchar a través de él, no el hablar del pensador que lo enuncia, sino este hablar del Logos que por ello mismo es palabra divina. Por eso, Heráclito afirma que la fuerza de este discurso es mayor que la palabra de la ley.

La filosofía no puede comprenderse como un discurso proveniente de un sujeto particular que se ofrece al público para ser adoptado como una creencia o una ideología. Ni siquiera si entendemos por "el público" a la clase intelectual, o a los que se ocupan profesionalmente de su enseñanza o de su difusión. La filosofía es una palabra que designa una disciplina que se basta a sí misma, que no requiere del asentimiento de nadie para alcanzar un poder sobre lo real. Su fuerza, si la tiene, radica únicamente en que ella diga o no diga efectivamente lo que es. Si lo dice, se trata de una auténtica filosofía, si no lo dice, quiere decir que no estamos autorizados a tratarla como tal. Y esta afirmación que parece tan arbitraria no debería extrañarnos tanto, pues exactamente lo mismo ocurre en el dominio del arte. En efecto, llamamos "arte" solo a aquellas obras que cumplen cabalmente las exigencias que el arte pone, y por eso somos capaces de distinguir entre aquellas obras que responden al mero propósito subjetivo de sus autores de que ellas puedan ser consideradas como tales, y aquellas que indudablemente poseen ese carácter. El "artista" no es el que unilateralmente se propone serlo, sino aquél que verdaderamente logra su propósito. A pesar de los factores distorsionadores, que sin duda existen, y entre los cuales el principal es el mercado, la mayoría de las veces es posible distinguir entre el arte verdadero y el que busca ser considerado como tal, sin serlo. Y si los hombres no son inmediatamente capaces de efectuar esta diferenciación, el tiempo sí es capaz de hacerlo y lo hace siempre despejando todas las dudas que pudieran haber surgido en su momento.

Con la filosofía sucede exactamente lo mismo, y por eso también en este caso la obra del hombre queda sujeta al veredicto del tiempo. Las filosofías exhiben su autenticidad cuando son capaces de mostrarse como referentes de época, como palabras lúcidas o signos precursores, y lisa y llanamente como cristalizaciones de la verdad de esa misma época en que surgen. El pensamiento filosófico se mide por aquello que es, por lo destinal, por el fatum, en todo caso, por algo que no deciden los humanos. No tiene que darle cuentas a nadie de lo que piensa, ni siquiera a lo humano en su más alta expresión. No hay tribunal que pueda juzgar una filosofía, porque es ella la que le presta una fundamentación a todo tribunal que pueda aspirar a tenerla. Esta autonomía no es, ni puede ser reconocida en el momento de su acontecer. La filosofía es post mórtem, es póstuma, pues su validez consiste en su propio acontecer. Lo que sucede como filosofía en un determinado momento de la historia es lo que efectivamente tiene que ser reconocido como tal en la posteridad. Sabemos que Nietzsche es un filósofo, porque efectivamente así ha quedado mostrado en nuestra época, en la cual, algunas 
de sus afirmaciones han adquirido el carácter de verdades insoslayables para quienes deseen comprenderla.

El lenguaje de la modernidad, en el cual un sujeto se dirige a otros sujetos, pero sobre todo la tradición religiosa que ha sido adoptada a su manera por la acción política y que se caracteriza por la búsqueda de prosélitos, ha instaurado como obvio el hecho de que una idea o un pensamiento solo adquiriría sentido en la medida en que se transforme en cosa pública. La doctrina de la fe es afirmada por los creyentes, los cuales tienen como deber buscar la adscripción a su fe por parte de otros creyentes. A partir de que la política pasó a ser una actividad dependiente de las voluntades individuales de los ciudadanos expresadas a través del voto, también el discurso político adquirió el mismo carácter que poseía la religión, basando su efectividad en el poder de convencimiento, en la capacidad de inducir una determinada acción a través de la adscripción de las voluntades a un ideario político.

Todo esto ha instaurado como obvio el hecho de que una idea solo tenga sentido en la medida en que sea afirmada por otros y, en lo posible, en la medida en que ella sea asumida por grandes grupos de seres humanos convencidos de su verdad. Pero la filosofía no tiene nada que ver con eso. Como ya lo hemos dicho, la filosofía no es un pensamiento del que puedan apoderarse las masas. La imagen más ridícula que podría imaginarse es la de una multitud de jóvenes agitando en sus manos la Crítica de la razón pura o la Metafísica de Aristóteles en una multitudinaria manifestación de apoyo, como ocurría con el Libro Rojo de Mao Tse Tung en China en los tiempos de la revolución cultural. La filosofía requiere una dedicación y un esfuerzo de tal rigurosidad, que solo unos pocos son capaces de entrar en sus dominios. Pero, más todavía, la filosofía siempre ha presentado como adversario suyo a las masas. El testimonio de Heráclito es transparente a este respecto: solo unos pocos son capaces de escuchar el Logos, la gran mayoría vive encerrada en su individualidad, de la misma manera como cuando nos quedamos dormidos le cerramos las puertas al mundo. Platón repite este pensamiento en el mito de la Caverna, exponiendo el proceso de ascensión al saber como una liberación que nos aparta del embobamiento en que vive la mayoría de los hombres, que solo son capaces de ver sombras. La Paideia en ningún caso podría comprenderse como un proceso de inserción exitosa en la vida social, como pretende la educación actual, pues ella busca exactamente lo contrario, el apartamiento del que ama el saber hacia el reino de las ideas, hazaña que solo una minoría sería capaz de llevar a cabo. Así, la filosofía es un esfuerzo individual y raro, que transforma al individuo en un ser inadaptado, pues la mayoría sigue tomando las sombras proyectadas en la pared de la caverna como si fuesen la única y verdadera realidad. El ejemplo de la muerte de Sócrates está siempre presente en la exposición de este mito. La pregunta lanzada por Platón al final del relato de la vuelta del hombre liberado al seno de la sociedad expuesta en el Libro VII de la Politeia no puede ser más clara: “ ¿No 
procederían a darle muerte, si pudiesen cogerle en sus manos y matarle, al que intentase desatarles y obligarles a la ascensión?" (PR, 516 e).

Y, sin embargo, lo que comprendemos es lo que compartimos con otro, la inteligencia y la comprensión son el territorio donde lo comprendido se hace común. Aquello que comprendo me une a otro y es en su territorio donde puede tener lugar esta unidad. Nada más cierto que esto. Pero en todos estos casos estamos hablando de una posibilidad realizada y que se ha hecho realidad, porque el que llega a comprender ha hecho el esfuerzo necesario para que ésta se cumpla. Y en el terreno de la filosofía, lo que posibilita esta comprensión es que ella se constituye como un lenguaje abierto, directo, nacido de una vocación de apertura hacia los otros. Si el pensamiento es necesariamente de lo común, aunque el acceso a esto solo lo lleven a cabo los que están dispuestos a consumar el esfuerzo que esta acción requiere, quiere decir que no se piensa solamente para sí, sino también para y por todos los hombres. Así, la filosofía tiene una doble universalidad, ella está abierta hacia la universalidad del Logos, del Uno-Todo, pero también lleva a cabo la universalidad de lo humano. Ella está disponible para cualquier ser humano que rehaga el camino del creador, y su mensaje es en la lengua de lo que reúne. La política, en cambio, como ya ha quedado dicho, es siempre particular y vive del enfrentamiento de posiciones diversas.

¿Pero por qué en muchos aspectos la historia de la filosofía se presenta como una lucha entre posiciones y escuelas, entre un juego de oposiciones que podría recordar al que se da en otras instancias con las cuales la estamos comparando? La respuesta es simple: porque ella está atravesada por todas las furias y mezquindades humanas y porque no todos los filósofos necesariamente cumplen a cabalidad con las exigencias que hemos expuesto aquí. Se es más o menos radicalmente un filósofo, de dónde la urgente necesidad de recuperar el sentido primigenio de la palabra "filósofo", voz que en el comienzo griego era un adjetivo y no un sustantivo, como ocurre hoy día. La filosofía debe entenderse como una opción de vida que puede ser más o menos radical, que da lugar a expresiones diversas que llevan todas las limitaciones de su tiempo, del lugar en que han surgido y de los individuos que han sido sus creadores, pero que por encima de estas circunstancias nunca deja de determinarse desde esa unidad a la que todos ellos han querido prestarle sus voces. La filosofía, tal como se muestra en Heráclito, es una dirección que toma la vida del espíritu en busca de un saber que no se constituya en Hybris, pero que aspire a lo más alto que puede aspirar el ser humano. Que sea el ser humano el que emprende este camino significa que no habrá jamás una filosofía purificada de las propias limitaciones que caracterizan al hombre, pero también, que toda filosofía digna de ese nombre se elevará necesariamente hacia lo más alto que a éste le sea deparado llegar. La filosofía es algo que se quiere, no es algo que se posea, su esencia sigue radicada en el filein, en el amor, en la afición, en la búsqueda y mientras el hombre sea hombre, ella mantendrá esta modalidad de ser en la que reside su grandeza y su limitación. 
La historia de Platón en Siracusa se muestra generalmente como el primer gran ejemplo de relación fracasada entre la filosofía y el orden político. Algunos han visto en esta aventura platónica un antecedente del desvío político de Heidegger, y hasta se cuenta una anécdota en la que un profesor de la Universidad de Friburgo encuentra al filósofo alemán en los patios de la universidad algunos días después de su renuncia al rectorado y lo saluda con la frase: “¿De vuelta ya de Siracusa, profesor?” Pero más allá de este lado anecdótico, la relación entre ambas experiencias es solo superficial. Platón viajó a Siracusa un poco forzado por su amistad con Dion, quien en un primer momento estaba convencido de que se podrían lograr grandes objetivos políticos si se llegaba a lograr el proyecto de convertir a Dionisio a la causa de la filosofía. El convencimiento de Dion de que esto era posible era tan sólido, que llegó hasta el extremo de convencer a Dionisio de enviar a Atenas un barco especial para trasladar a Platón a Siracusa. El objetivo del filósofo y de su amigo era el de educar al tirano, y en ningún caso una adscripción a un movimiento político. En realidad, Platón, en la explicación de su desventurada experiencia se abstiene en todo momento de entrar en el terreno de la política y puede decirse que su colaboración con Dion fue siempre estrictamente educativa y filosófica. Él parte del convencimiento de que únicamente transformando a los gobernantes en filósofos pueden lograrse objetivos de buen gobierno. Para Platón, la filosofía conducía necesariamente a una manera de vivir en la honestidad, en la serenidad y en la justicia. Su proyecto no era político, sino educativo, buscaba incorporar en aquellos que gobiernan el espíritu de la filosofía, incluyendo en él una vida alejada de los placeres mundanos y consagrada al cultivo del espíritu. Es asegurando la conducta ética que se puede lograr que los gobernantes cumplan con su deber cabalmente y piensen en el bien común, antes de que en los beneficios personales. Por lo tanto, sus objetivos políticos en Siracusa son bastante modestos. "Pues con ganar a mi causa a un solo hombre, habría conseguido la cabal realización de toda clase de bienes" (PC, p. 67).

Por consiguiente, al error de Platón radica en haber confundido el plano ético y el plano político, pensando ingenuamente que era posible la reforma interior de los ciudadanos y en particular del gobernante, a través de la educación. Pero su actitud frente a la política fue siempre bastante más cauta de lo que se afirma habitualmente. En primer lugar, siendo joven, y además siendo pariente de uno de los 30 tiranos que se tomaron el poder en Atenas con posterioridad a la guerra del Peloponeso, al serle solicitada su colaboración con el nuevo gobierno, él decide mantenerse al margen y de su distanciamiento da testimonio la Carta VII: “...les dediqué mi más apasionada atención, a ver lo que conseguían" (PC, p. 61). Por supuesto que lo que hacían no le pareció nada bien y, entre otras cosas, porque su maestro Sócrates se opuso a ellos hasta el punto de negarse a cumplir una de sus órdenes que afectaban la vida de un ciudadano inocente. Una vez que se depuso el gobierno de los tiranos, Platón afirma haber sentido nuevamente deseos de participar activamente en la política, pero la condena y ejecución de Sócrates terminan por desencantarlo definitivamente. Su conclusión está expresada claramente: no vale la pena meterse en los asuntos públicos si 
no se tienen "amigos íntimos y compañeros dignos de confianza" entre los que gobiernan. Así, la conclusión de Platón no es tan alejada del rechazo de Heráclito. En la carta VII se afirma claramente: “...tanto la letra como el espíritu de las leyes se iba corrompiendo y el número de ellas crecía con extraordinaria rapidez. De esta suerte yo, que al principio estaba lleno de entusiasmo por dedicarme a la política, al volver mi atención a la vida pública y verla arrastrada en todas direcciones por toda clase de corrientes, terminé por verme atacado de vértigo" (PC, p. 63).

La idea que Platón extrae de todas estas experiencias es bastante poco entusiasta, pues le parece que todos los regímenes políticos de la época están mal gobernados. Por eso, se comprende su salida, que por lo demás explica su experiencia en Siracusa, pero también su solución al problema político. " $Y$ me vi obligado a reconocer, en alabanza de la verdadera filosofia, que de ella depende el obtener una visión perfecta y total de lo que es justo, tanto en el terreno político como en el privado, y que no cesará en sus males el género humano hasta que los que son recta y verdaderamente filósofos ocupen los cargos públicos, o bien los que ejerzan el poder en los Estados lleguen, por especial favor divino, a ser filósofos en el auténtico sentido de la palabra" (PC, p. 63). Y esto significa que Platón, definitivamente desesperanzado de los políticos, decide confiar únicamente en los filósofos para hacer posible una sociedad más justa.

Para ser justos con Platón, debemos reconocer que en sus planes no ha habido tampoco un exceso de optimismo o de juicio utópico en relación con las posibilidades reales de lograr sus propósitos. Todos sus planes son muy generales y se remiten a terminar con los excesos de una tiranía que no tenga un poder ciudadano de contrapeso: "No sometáis a Sicilia, ni tampoco ningún otro Estado, a señores absolutos -al menos este es mi parecer-sino a las leyes; pues ello no redunda en beneficio ni de los que someten, ni de los sometidos" (PC, p. 77). Estas y otras recomendaciones semejantes, como por ejemplo, que gobiernen personas de una cierta edad y de probada honradez, o que los gobiernos no sean ni tiránicos ni demasiado liberales, o que entre la tiranía y el libertinaje se elija el gobierno de un rey asistido por una asamblea, son todos los pronunciamientos políticos de Platón. Por otra parte, ni siquiera muestra demasiado optimismo acerca de las reales posibilidades de educar al tirano, como Dion le ha propuesto, pues Platón sabe que si no hay disposiciones naturales que inciten a los hombres por la senda de la filosofía, tampoco es plausible el logro educativo: "Pero si las disposiciones son naturalmente malas, y este es, en la mayoría de las personas, el estado natural del alma, tanto por lo que se refiere a la capacidad de aprender, como a lo que se llama carácter moral (otras veces tal estado es consecuencia de una corrupción), a estas personas ni el propio Linceo podría hacerlos ver con claridad" (PC, p. 91). Las últimas palabras de la Carta VII instan a los nuevos vencedores, partidarios de Dion y enemigos de Dionisio, a lograr una situación de concordia entre las partes y, a pesar de los males sufridos por Platón en la corte de este último, no son en ningún caso dictadas por un ánimo de venganza.

Por tanto, poco tiene Platón que ver con la política y no es justo reprocharle ni una falta a la filosofía ni una falta a la política, pues si bien en su aventura de Siracusa aceptó por amistad un juego en el que más le hubiera valido mantenerse al margen, 
mientras se mantuvo en él, actuó como verdadero filósofo tratando en todo momento de resguardar su libertad amenazada.

Para no rebasar los límites de un artículo como este, nos hemos visto obligados a dejar de lado problemas de enorme importancia, como por ejemplo, el de la incidencia de la política en la filosofía y el de la incidencia de la filosofía en la política. Ellos nos hubieran llevado a hacer una historia de sus mutuas interacciones, cosa que esperamos hacer en otros trabajos. Sin embargo, lo ya dicho nos permite responder a la siguiente pregunta: ¿Es legítimo hacer política queriendo ser filósofo?

Si por política se entiende una actividad que conlleve una renuncia a la libertad de pensamiento, la respuesta es no, pero si se trata de hacernos cargo de nuestro papel de ciudadanos, y se entiende este compromiso, no como una guerra o una cruzada por el bien, o en contra del mal, sino como el deseo asumido como tal del advenimiento de un cierto tipo de sociedad que sea coherente con el ejercicio libre del pensamiento, la respuesta puede ser afirmativa. Por supuesto, la adscripción a un partido, en cuanto ella significa un compromiso con un pensamiento que se asume colectivamente, es altamente poco recomendable y generadora de eventuales conflictos que es más prudente evitar. Sin embargo, como ciudadanos, todos tenemos el deber de expresar nuestras preferencias, aunque para un filósofo esto no puede ser hecho en el desconocimiento de que toda acción política es una apuesta por el futuro, apuesta que la historia misma resolverá sobre si era acertada o no. El filósofo sabe que no es fácil determinar qué es lo justo, qué es lo injusto, y desea mantener el rigor del cuestionamiento frente a estas cosas. El rigor está en esta distancia exigida por el cuestionamiento absoluto en que se asienta la propia condición humana. Solo podemos estar seguros de lo incierto de nuestra propia situación, de lo inquietante que es para nosotros abordar nuestra vida sin tener respuestas definitivas sobre las cosas que más nos importan. Podemos participar en toda lucha, pero siempre que esta no vaya en contra de nuestra responsabilidad principal. En este equilibrio está precisamente la dificultad, y no existe ninguna forma de salir de esta postura de equilibrista. Sería una ingenuidad pretender lo contrario: una filosofía que se determina desde la política, no es filosofía. Lo mismo ocurre con la religión: una filosofía que se determina desde la religión, no es filosofía. Solo es filosofía un pensamiento que se autodetermina desde el cuestionamiento radical, que, en definitiva, no es otra cosa que la esencia de lo humano. La esencia de lo humano es lo inhumano de su condición. La vida del hombre es irreductible a toda comprensión en términos estrechamente humanos, a toda racionalidad, a todo orden que nosotros seamos capaces de planificar, producir o administrar.

En este sentido, la filosofía sigue siendo el corazón de las humanidades, pues ella es la que preserva de mejor manera la irreductibilidad del misterio del ser (y, dentro de él, el abismo humano) que sirve de base a toda comprensión equilibrada de lo 
propiamente humano. "Humanidades" son todas aquellas disciplinas que se limitan al "ver", y renuncian al "conocer" -en el sentido de las ciencias naturales- disciplinas que poseen su propio rigor, no basado en la exactitud ni en el dominio de su objeto, sino en el resguardo de lo abismal de la esencia humana. La política, en cambio, pertenece al ámbito de la pretensión de un dominio humano sobre el acontecer histórico: carece por lo tanto del espíritu maternal, "pasivo", puramente receptivo de las humanidades. Frente al dominio, las humanidades buscan la apertura desde la cual habla lo que no es humano, "pasividad" que es propia de todo verdadero crear. Asimismo, en cuanto creación, todo trabajo en este terreno, aunque apunta necesariamente hacia lo colectivo, se mantiene siempre como un esfuerzo individual.

Heidegger asume su cargo de rector de la Universidad de Friburgo el 2 de abril de 1933 y se mantiene en él hasta su dimisión, el 24 de abril de 1934. Su compromiso militante con el nazismo se sitúa a partir del 1 de mayo de 1933, pero sus simpatías por este movimiento provienen de antes de esa fecha. 1933 es un año clave en la historia alemana, pues marca el momento del ascenso de Hitler al poder. Las políticas antisemitas ya comienzan a mostrar en todos los planos de la sociedad sus terribles consecuencias y el exacerbado nacionalismo se encuentra a la orden del día en los análisis políticos oficiales y en las principales directrices del gobierno. Heidegger participa de este embobamiento nacional a través de declaraciones, alocuciones y artículos en los que no faltan ni los elogios al nuevo Canciller ni el "Sieg Heil" alemán. Con posterioridad a su renuncia como rector comienza un período de crítica y de alejamiento en relación con el movimiento nacionalsocialista, pero la sombra de sus años de militancia nazi caerá sobre su obra posterior y interferirá completamente en su correcta comprensión. A partir de 1945, Heidegger intenta desmarcarse completamente de su anterior compromiso, pero confundido por las lamentables consecuencias que ha tenido su paso por la política, se le hace imposible volver a posicionarse en este sentido, motivo por el cual muchas de sus actitudes anteriores quedan en la ambigüedad.

El compromiso de Sartre con los comunistas se hace explícito en su participación de la reunión del Movimiento Mundial por la Paz en 1952, en Viena. Posteriormente, en 1954, viaja a la URSS y en una serie de entrevistas concedidas al diario Liberation, a su vuelta, hace el elogio del régimen, llegando a hacer afirmaciones que denotan una pérdida completa de su sentido crítico, como por ejemplo, que en la URSS ya existe un tipo de hombre nuevo, de que en el país hay una total libertad de crítica y de que muy pronto el ingreso per cápita de los obreros rusos será superior al del obrero francés. A partir de ese momento, la lucidez del pensador francés aparece gravemente puesta en duda y entra en una escalada de afirmaciones de orden político que lo llevan hasta su compromiso con los maoístas al final de su vida y a la serie de escritos y entrevistas políticas en las que el filósofo francés pareciera haber perdido completamente la ruta, hasta el punto de renegar de todas sus obras anteriores a este tipo de compromisos, 
dentro de las cuales están sus principales aportes a la literatura y al pensamiento ( $E l$ ser y la nada, La Náusea y las novelas de la serie de Los caminos de la libertad).

Los desvaríos políticos de Sartre resultan hoy día tanto o más graves que los escandalosos actos de compromiso de Heidegger con el nazismo. Sin embargo, curiosamente, en los círculos intelectuales y académicos pareciera haber mucho mayor condescendencia con el compromiso de Sartre con formas extremistas del marxismo, que con el compromiso de Heidegger con el nazismo. A juzgar por el número de víctimas de ambos regímenes, no habría gran diferencia entre ellos, tampoco si juzgamos el carácter voluntarista de uno y otro, o de sus atentados en contra de las libertades cívicas, en contra de la libertad de pensamiento o en contra de los derechos humanos. ¿Qué ha ocurrido entonces? ¿Qué fuerzas demoníacas han hecho que dos de las mentes más lúcidas del siglo hayan caído ingenuamente en un compromiso con las ideologías más nefastas de su tiempo? ¿Qué ha hecho que Heidegger se entusiasmara con el nazismo, llegando hasta considerarlo como una fuerza de la cual se podía afirmar con pretensiones de legitimidad que era la verdadera solución frente al peligro de expansión del nihilismo?

Nuestra intención por ahora no es responder a estas preguntas. Pero si lo dicho hasta ahora es cierto, lo que corresponde en ambos casos es juzgar estas acciones desde las exigencias que pone la propia filosofía. Los enjuiciamientos políticos o éticos que se han hecho - predominantemente en el caso de Heidegger- tienen una justificación, pero a los filósofos debería importarles por encima de todo de qué manera estas acciones se salen de lo que podría llamarse la "deontología" de la filosofía, que exige, en primer lugar, el distanciamiento necesario para no acabar con la lucidez. Las dos experiencias señaladas son en primer lugar errores contra la filosofía, es su propósito esencial el que ha sido pasado a llevar, y si bien puede ser legítimo juzgar estas desviaciones desde perspectivas éticas o incluso políticas, lo más grave no reside en ello, pues lo más grave para un filósofo es negar aquello que está en el centro de su vida, la decisión que lo ha empujado hacia el camino de la fidelidad consigo mismo y con la tarea que se ha dado.

Por supuesto que no es aconsejable ser demasiado riguroso frente a los errores humanos, sobre todo en casos en los que el aporte a la humanidad está más que claro. ¿Quién no ha pasado por desvaríos durante una larga vida? Heidegger y Sartre, a pesar de su grandeza como pensadores, no fueron capaces de atravesar el mal de su siglo sin contagiarse con él. Su protagonismo intelectual no los salvó de las corrientes de opinión, ni de los entusiasmos masivos, ni de las esperanzas exacerbadas, razón de más para tomar una vez más en cuenta la dificultad existente en la tarea de asumirse como filósofo. Lo grande en ambos, a pesar de sus errores, queda en pie y se mide por la misma vara que Heráclito en su fragmento 43 le puso a todos los que intenten seguir este camino: "Más que los incendios, hay que apagar la Hybris" (FH, p. 187). Es eso lo que pierde a los hombres y entre ellos, a los filósofos. Si los tiempos que vienen son tiempos propicios para el pensamiento libre, entonces los trágicos ejemplos de estos dos pensadores pueden servir para que los futuros filósofos se aparten de las ilusiones del presente y vuelvan rectamente su mirada desde los cantos de sirena del "esto", 
del "aquí" y del "ahora", para mantenerse como los vigilantes del Logos, que habla siempre en la lengua de la universalidad y de lo común, pero que, por eso mismo, se mantiene como la palabra que salvaguarda la historia y redime a los que fueron y a los que son, asegurando su pertenencia a él. "Alzarse en contra de lo que está ahí y hacerse guardianes de los vivos y de los muertos" (HF, Fragmento 20, p. 133).

Obras citadas y sus abreviaturas

CPU Giordano Bruno (1982), Cause, principe et unité. Paris: Presses Universitaires de France (PUF).

HF Heráclito (1986), Fragments. Texto establecido, traducido y comentado por Marcel Conche. Paris: Presses Universitaires de France (PUF). En la numeración de los fragmentos se ha respetado la edición de Diels y Kranz.

PC Platón(1954), Cartas. Edición bilingüe y prólogo por Margarita Toranzo, revisada por José Manuel Pabón y Suárez de Urbina. Madrid: Instituto de Estudios Políticos.

PE Plotino (1998), Enéadas V-VI. Introducciones, traducciones y notas de Jesús Igal. Madrid: Biblioteca Clásica Gredos.

PP Jean Paul Dumont, con la colaboración de Daniel Delattre y Jean-Louis Poirier (1988), Les Présocratiques. Paris: Éditions Gallimard (Colección La Pléiade).

PR Platón (1969), La República. Edición bilingüe, traducción, notas y estudio preliminar por José Manuel Pabón y Manuel Fernández Galiano. Madrid: Instituto de Estudios Políticos.

UB F. Nietzsche (1954), Unzeitgemässe Betrachtungen, "Schopenhauer als Erzieher", en Friedrich Nietzsche, Werke in drei Bänden (edición de Karl Schlechta). München: Karl Hanser Verlag. 